\title{
ANALISIS PERILAKU ATLET PAB FORKI DIY DALAM MENDUKUNG PERFORMANCE LATIHAN SELAMA PANDEMI COVID-19
}

\author{
Widha Srianto ${ }^{1}$, Untung Nugroho ${ }^{2}$ \\ ${ }^{1}$ Program Studi Pendidikan Jasmani, FKIP UTP Surakarta \\ Email: widha.srianto@lecture.utp.ac.id \\ ${ }^{2}$ Program Studi Pendidikan Jasmani, FKIP UTP Surakarta \\ Email: ntoeng87@yahoo.co.id
}

\begin{tabular}{l}
\hline Artikel Info \\
\hline \\
Koresponden penulis: Widha Srianto \\
Email. widha.srianto@lecture.utp.ac.id \\
$\square$ Diterima 4 Januari 2021 \\
$\square$ Direview 12 Juli 2021 \\
$\square$ Disetujui 16 Juli 2021 \\
$\square$ Dipublikasi 17 Juli 2021
\end{tabular}

Kata Kunci:

Karate, Performance, Latihan, , Covid19.

$\underline{\text { Keywords: }}$

Karate, Performance, Exercise, Covid-19.

\begin{abstract}
Abstrak
Peneltian ini bertujuan untuk mengetahui perilaku atlet PAB FORKI DIY dalam mendukung performance latihan selama pandemic Covid 19. Penelitian ini merupakan penelitian deskriptif analisis dengan metode survey. Populasi dalam penelitian ini adalah atlet PAB Forki DIY, sample penelitian menggunakan total sampling berjumlah 15 atlet. Instrumen yang digunakan dalam penelitian ini berupa kuesioner. Hasil penelitian yaitu: 1) Indikator perilaku hubungan sosial didapatkan hasil persentase $74,67 \%$, dengan hasil analisis sebagai berikut: a) $93.33 \%$ berkomunikasi dengan orang dalam melaksanakan program latihan, b) $80.00 \%$ latihan karena motivasi dari orang tua, c) $73.33 \%$ latihan karena motivasi dari pelatih, d) $66,67 \%$ memiliki teman latihan, dan e ) $60.00 \%$ menambah jam latihan privat dengan pelatih. 2) Indikator perilaku ekspresif didapatkan hasil persentase $73,33 \%$, dengan hasil analisisi sebagai berikut: a) $93.33 \%$ memiliki motivasi tinggi dalam berlatih selama masa pandemic covid-19, dan b) $53.33 \%$ jenuh latihan selama masa pandemi covid19. 3) Indikator perilaku peran didapatkan hasil persentase $64,17 \%$, dengan hasil analisis sebagai berikut: a) $80.00 \%$ selalu latihan mandiri selama masa pandemic covid-19, b) $80.00 \%$ menjalankan program latihan dari pelatih, c) $80.00 \%$ antusias mencari referensi latihan selama pandemic covid-19, d) $80.00 \%$ mengatur gizi selama untuk mempertahankan performance latihan, e) $66.67 \%$ selalu menambah latihan sendiri diluar program dari pelatih, f) $60.00 \%$ mengatur tidur selama untuk mempertahankan performance latihan, g) $40.00 \%$ selalu mengikuti latihan yang bersifat online, h) $26.67 \%$ mencatat program latihan yang telah dijalankan.
\end{abstract}

\begin{abstract}
This study aims to determine the behavior of PAB FORKI DIY athletes in supporting training performance during the Covid 19 pandemic. This study is a descriptive analysis study with a survey method. The population in this study were PAB Forki DIY athletes, the research sample used a total sampling of 15 athletes. The instrument used in this study was a questionnaire. The results of the study are: 1) Indicators of social relations behavior, the percentage results are $74.67 \%$, with the results of the analysis as follows: a) $93.33 \%$ communicate with people in implementing the exercise program, b) $80.00 \%$ exercise due to motivation from parents, c) $73.33 \%$ of training due to motivation from the trainer, d) $66.67 \%$ have training partners, and e) $60.00 \%$ add hours of private practice with the trainer. 2) The indicator of expressive behavior obtained a percentage of $73.33 \%$, with the results of the analysis as follows: a) $93.33 \%$ have high motivation in practicing during the covid-19 pandemic, and b) $53.33 \%$ are saturated with exercise during the covid-19 pandemic. 3) Role behavior indicators obtained a percentage of $64.17 \%$, with the following analysis results: a) $80.00 \%$ always practice independently during the covid-19 pandemic, b) $80.00 \%$ carry out training programs from coaches, $c$ ) $80.00 \%$ enthusiastically seek references exercise during the covid-19 pandemic, d) $80.00 \%$ regulates nutrition while maintaining exercise performance, e) $66.67 \%$ always adds to their own training outside the trainer's program, $f$ ) $60.00 \%$ regulates sleep during exercise to maintain exercise performance, g) $40.00 \%$ always follows online training, h) $26.67 \%$ recorded the exercise program that had been carried out.
\end{abstract}




\begin{tabular}{|c|c|}
\hline & Journal STAND: Sports and Development \\
umipa Sumalmya & $\frac{\text { http://jurnal.unipasby.ac.id/index.php/stand/about/submissions }}{\text { jurnal.stand@unipasby.ac.id }}$
\end{tabular}

\section{PENDAHULUAN}

Majunya perkembangan olahraga karate baik dari tingkat Daerah, Nasional, maupun Internasional memberi kesempatan setiap atlet untuk meraih prestasi, mendidik mental dan mengasah keterampilan dalam bertanding. Untuk berprestasi seseorang harus melalui suatu proses latihan yang berlangsung selama bertahun-tahun, dan mengeluarkan banyak pengorbanan baik tenaga, dana dan waktu. Proses yang harus dilalui untuk dapat berprestasi adalah proses latihan, berlatih adalah suatu proses penyempurnaan kualitas atlet secara sadar, untuk mencapai prestasi maksimal dengan diberi beban fisik dan mental secara teratur, terarah, meningkat, dan berulang-ulang waktunya.

Seiring dengan berkembangnya olahraga karate hal itu memacu para pembina, atau pelatih karate untuk melahirkan atlet-atlet yang berprestasi di setiap pertandingan. Sebenarnya, DIY merupakan daerah yang sangat bagus untuk melahirkan atlet-atlet yang berprestasi karena DIY sebagai kota pelajar dimana banyak penduduk yang berusia, muda, yang dapat dijadikan sebagai sasaran untuk pembinaan prestasi olahraga karate. Ditambah lagi dengan adanya penyaringan `bibit atlet daerah dimana atlet-atlet karate yang berprestasi mendapat kemudahan untuk melanjutkan sekolahnya kejenjang selanjutnya. Dengan adanya pembinaan atlet berbakat DIY sesuai dengan program dinas pendidikan, pemuda, dan olahraga diharapkan dapat meningkatkan kualitas atlet untuk kemajuan olahraga di Indonesia.

Mayoritas program latihan selama masa pandemi covid-19 adalah program work from home (WFH), yaitu program yang diberikan pelatih kepada atlet untuk dilakukan sendiri di rumah. Kasus pandemi covid-19 telah menimbulkan dampak yang beragam bagi setiap atlet. Ketidaksiapan pelatih, orang tua dan atlet dalam menghadapi pandemi covid-19 berakibat negatif bagi perilaku atlet terhadap performa latihan atlet PAB FORKI DIY. Karakteristik atlet di usia anak-anak memiliki kecenderungan emosional yang tidak stabil sangat memungkinkan terjadinya mirror of effect dalam perkembangan perilaku. Sehingga perlu adanya analisis perilaku Atlet PAB Forki DIY dalam mendukung performance latihan selama pandemi covid-19.

\section{KAJIAN LITERATUR DAN PENGEMBANGAN HIPOTESIS \\ Karate}

Althought the term karate is well-known, it is more correct to refer to karate-do as as this martial art can be regarded as a budo form. Karate, which literally means "empty hand", exsist primarily of unarmed techniques. It is characterised by hand and arm techniques (punches), leg techniques (kicks and leg sweeps), and low body positions. Dijelaskan bahwa meskipun istilah karate telah banyak dikenal, lebih tepat mengartikan karate sebagai seni beladiri atau bentuk budo. Karate, secara 


\begin{tabular}{|c|c|}
\hline & Journal STAND: Sports and Development \\
umipa Sumalmya & $\frac{\text { http://jurnal.unipasby.ac.id/index.php/stand/about/submissions }}{\text { jurnal.stand@unipasby.ac.id }}$
\end{tabular}

literatur, berarti tangan kosong, muncul pertama kali sebagai teknik-teknik tanpa tangan/tangan kosong. Karate dikarakteristikan dengan teknik-teknik tangan (pukulan) dan lengan (tangkisan), teknik kaki (tendangan dan sapuan), dan menggunakan posisi tubuh bagian bawah. Menurut Widha (2014: 59) teknikteknik karate yang dilatih dan dikontrol secara baik sesuai dengan keinginan seseorang dengan sendirinya secara spontanitas akan bergerak langsung pada sasaran yang tepat dan bertenaga.

\section{Covid-19}

C0vid-19 (sebelumnya disebut dengan 2019-nCov) adalah virus jenis baru yang belum pernah diidentifikasi sebelumnya pada manusia. Manifestasi klinis biasanya muncul dalam 2 hari hingga 14 hari setelah paparan. Tanda dan gejala umum infeksi coronavirus antara lain gejala gangguan pernapasan akut seperti demam, batuk serta sesak napas. Pada kasus yang berat dapat menyebabkan pneumonia, sindrom pernapasan akut, gagal ginjal, dan bahkan kematian. Mengingat masih terbatasnya informasi tentang karakteristik covid-19 maka strategi pencegahan dan pengendalian infeksi digunakan untuk mencegah atau membatasi penularan infeksi dengan menerapkan kewaspadaan terhadap kontak, percikan dahak langsung (droplet) dan penularan melalui udara (airborne).

Menurut (WHO, 2020) World Health Organization memberi nama virus baru tersebut severe acute respiratory syndrome corona virus-2 (SARS-CoV-2) dan nama penyakitnya sebagai Corona virus disease 2019 (COVID-19). Menurut WHO dalam Yuliana $(188,2020)$ Saat ini ada sebanyak 65 negara terinfeksi virus corona. Menurut data WHO pertangga 12 Maret 2020 jumlah penderita 90.308 terinfeksi covid-19. Di Indonesia sampai saat ini terinfeksi 2 orang. Angka kematian mencapai 3.087 atau $2.3 \%$ dengan angka kesembuhan 45.726 orang. Terbukti pasien konfrimasi covid-19 di Indonesia berawal dari suatu acara di Jakarta dimana penderita kontak dengan seorang warga Negara asing (WNA) asal Jepang yang tinggal di Malaysia. Setelah pertemuan tersebut penderita mengeluhkan demam, batuk dan sesak napas.

\section{Perilaku Atlet}

Hurlock (2003: 261) perilaku sosial adalah istilah yang digunakan untuk menggambarkan perilaku umum yang ditunjukkan oleh individu dalam masyarakat, yang pada dasarnya sebagai respon terhadap apa yang dianggap dapat diterima atau tidak diterima oleh kelompok sebaya seseorang. Perilaku tersebut ditunjukkan dengan perasaan, tindakan, sikap keyakinan, kenangan atau rasa hormat terhadap orang lain. Perilaku sosial adalah aktifitas fisik dan psikis seseorang terhadap orang lain atau sebaliknya dalam rangka memenuhi diri atau orang lain yang sesuai dengan tuntutan sosial. Sedangkan yag dimaksud dengan perilaku atlet adalah aktifitas fisik maupun pisikis yang menggambarkan perilaku atlet secara umum baik dalam kegiatan 


\begin{tabular}{|c|c|c|}
\hline & Journal STAND: Sports and Development \\
umipa Sumalaya & http://jurnal.unipasby.ac.id/index.php/stand/about/submissions \\
\hline
\end{tabular}

bermasyarakat maupun kegiatan dalam berlatih maupun bertanding yang melekat pada diri atlet. Terdapat faktor internal dan faktor eksternal yang mempengaruhi perilaku, faktor internal adalah yang berasal dari dalam diri seseorang, antara lain: insting, motif dari dalam dirinya, sikap serta nafsu. Faktor eksternal adalah faktor yang berasal dari luar diri seseorang, yaitu faktor iklim atau cuaca, faktor lingkungan, faktor dari status ekonomi.

\section{METODE}

\section{Metodologi penelitian}

Penelitian ini merupakan penelitian deskriptif dengan metode survei.. Menurut Hadari (2007: 67) dapat diartikan sebagai prosedur pemecahan masalah yang diselidiki dengan menggambarkan/melukiskan keadaan subyek/obyek penelitian (seseorang, lembaga, masyarakat dan lain-lain) pada saat sekarang berdasarkan fakta-fakta yang tampak. Menurut Azwar (2012: 7) penelitian deskriptif adalah penelitian yang bertujuan untuk menggambarkan secara sistematik dan akurat fakta dan karakteristik mengenai populasi atau mengenai bidang tertentu

Populasi adalah wilayah generalisasi yang terdiri atas: objek/subjek yang mempunyai kualitas dan karakteristik tertentu yang ditetapkan oleh peneliti untuk dipelajari dan kemudian ditarik kesimpulannya (Sugiyono, 2013: 119). Populasi dalam penelitian ini adalah atlet PAB Forki DIY dengan menggunakan teknik sampling yang digunakan adalah total sampling.

\section{Instrumen Penelitian}

Terdapat tiga langkah yang harus ditempuh dalam penyusunan instrumen, ketiga langkah tersebut adalah mendefisinikan konstrak, menyidik faktor, dan menyusun butirbutir pernyataan.

1. Mendefinisikan konstrak

Konstrak variabel penelitian ini adalah persepsi atlet PAB Forki DIY terhadap perilaku latihan yang dilakukan selama pandemic covid-19. Variabel utama pada penelitian ini yang diukur adalah perilaku atlet PAB Forki DIY dalam mendukung performa latihan.

2. Menyidik Faktor

Langkah selanjutnya yaitu menyidik faktor, yaitu tahap yang bertujuan untuk menandai faktor-faktor yang ditemukan dalam konstrak yang akan diteliti. Faktorfaktor tersebut meliputi: perilaku latihan, Setelah menyidik faktor maka langkah selanjutnya adalah membagi faktor menjadi indikator-indikator yang lebih spesifik, yaitu terkait dengan perilaku peran, perilaku hubungan sosial, dan perilaku ekspresif.

3. Menyusun butir

Langkah yang terakhir yaitu menyusun butir pernyataan berdasarkan faktor-faktor yang menyusun konstrak. Butir-butir pernyataan merupakan penjabaran dari isi faktor, berdasarkan faktor-faktor kemudian disusun butir-butir soal yang dapat memberikan gambaran 


\begin{tabular}{|c|c|c|}
\hline & Journal STAND: Sports and Development \\
umipa Sumalaya & http://jurnal.unipasby.ac.id/index.php/stand/about/submissions \\
\hline
\end{tabular}

mengenai kuesioner yang akan dipakai dalam penelitian ini. Menurut Sugiyono (2011: 103) langkah-langkah dalam penyusunan instrumen penelitian dilihat dari variable-variabel penelitian yang ditetapkan untuk diteliti, dan selanjutnya indikatorindikator yang akan diukur, dari indikator ini kemudian dijabarkan menjadi butir-butir pertanyaan atau pernyataan.

\section{Uji Instrumen}

Kuesioner penelitian ini merupakan kuesioner yang dibuat oleh peneliti, setelah peneliti selesai membuat butir-butir pernyataan tahap selanjutnya adalah melakukan uji ahli (Expert Judgement), dan selanjutnya dilakukan uji coba penelitian, uji validitas dan reliabilitas instrumen.

\section{Uji Ahli}

Dilakukan oleh expert praktisi dan akademisi, yang memahami tentang perilaku atlet menjelang pertandingan. Expert praktisi dilakukan oleh Fitriyadi Wahyono, Pelatih PAB Forki DIY yang memegang lisensi DAN IV. Sedangkan expert akademisi dilakukan oleh Teguh Andi Wibowo, M.Or, sebagai dosen yang mengajar matakuliah karate. Jenis validasi ini adalah validasi konstruk, yaitu: mendiskusikan konsep dengan ahli-ahli yang kompeten di bidang konsep yang akan diukur. Pendapat para ahli dan peneliti dicari kesamaannya, lalu berdasarkan kesamaan tersebut kemudian disusun kerangka konsep yang dapat diwujudkan berupa pertanyaan- pertanyaan yang akan dimasukan ke dalam kuisioner atau angket.

2. Uji Coba Instrumen

Uji coba instrumen dimaksudkan untuk memperoleh instrumen yang valid dan reliabel. Baik buruknya suatu instrumen dapat ditunjukkan melalui tingkat kesahihan (validitas) dan tingkat keandalan (reliabilitas) instrumen itu sendiri sehingga instrumen tersebut dapat mengungkap data yang dibutuhkan untuk menjawab permasalahan penelitian sebagaimana yang telah dirumuskan sebelumnya. Uji coba instrumen dilakukan pada tanggal 17 dan 18 November tahun 2020 dengan responden atlet PAB Forki DIY berjumlah 15 orang yang merupakan subjek utama penelitian ini.

\section{Uji Validitas}

Uji validitas menggunakan biserial correlation atau korelasi point biserial, Salah satu teknik analisis korelasi bivarit yang biasanya digunakan untuk mencari korelasi antara 2 variabel, yang satu berbentuk kontinum (jumlah keseluruhan angket). Variabel kedua berbentuk dikotomi (berupa skor 1 untuk jawaban ya dan 0 untuk jawaban tidak). 


\begin{tabular}{|c|c|c|}
\hline & Journal STAND: Sports and Development \\
umipa Sumalaya & http://jurnal.unipasby.ac.id/index.php/stand/about/submissions \\
\hline
\end{tabular}

Tabel 1: Rumus korelasi point biserial

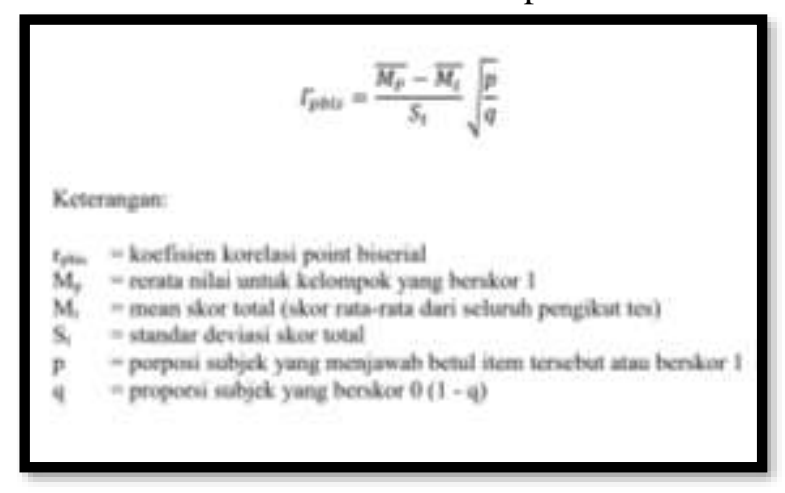

4. Uji Reliabilitas Instrumen

Menurut Suharsimi Arikunto (2003: 229) angket alternatif yang di klasifikasikan dengan skor 1 dan 0 atau 2 dan 1 menggunakan teknik Kuder dan Richardson 20 (K - R 20).

Tabel 2: Rumus K - R 20

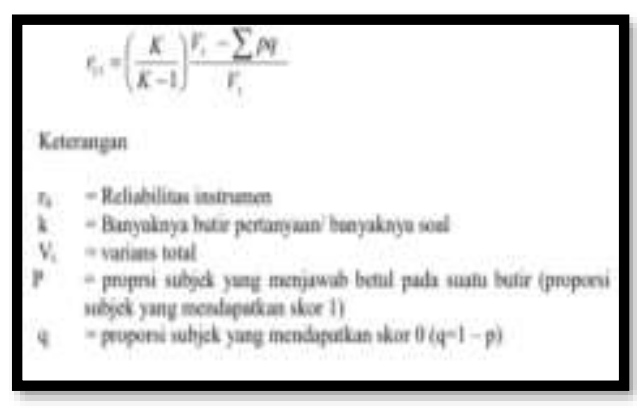

\section{Teknik Analisis Data}

Teknik analisis data dengan cara pengambilan data, data yang dikumpulkan berupa data primer dengan menggunakan data angket/ kuesioner. Proses pengumpulan data ini dilakukan dengan membagikan angket tertutup kepada seluruh responden, untuk memperoleh data tentang kecemasan terhadap responden. Data dianalisis secara deskriptif dengan persentase. Data yang telah didapat selanjutnya data akan dianalisis menggunakan persentase dengan rumus sebagai berikut (Anas Sudijono, 2006: 43), P = F / N x $100 \%$.

Keterangan: $\quad \mathrm{P}=$ Persentase yang dicari

$$
\mathrm{F}=\text { Frekuensi }
$$

$\mathrm{N}=$ Number of Cases (jumlah individu)

\section{HASIL DAN PEMBAHASAN}

\section{Hasil Uji Coba Instrumen}

Uji coba dilakukan terhadap instrumen pengukuran yang berupa angket/kuesioner dengan tujuan untuk menguji validitas dan realibilitas dan kesahihan instrument yang digunakan. Uji coba instrument dilakukan pada tanggal 17 dan 18 November tahun 2020 dengan responden atlet PAB Forki DIY berjumlah 15 orang.

\section{Uji Validitas}

Butir-butir intrumen dianalisis dengan menggunakan exel. Uji validitas menggunakan teknik korelasi point biserial dikarenakan datanya dikotomi (bersifat benar atau salah). Semua intrumen dalam hal ini item/indikator dikatakan valid karena nilai $r$ hitung $>r$ tabel atau mempunyai nilai Sig < tingkat signifikan, yaitu dengan hasil $r$ tabel adalah 0.3 , dengan demikian dari hasil uji coba butir pertanyaan dinyatakan valid karena $\mathrm{r}$ hitung $>0.3$. 


\begin{tabular}{|c|c|c|}
\hline & Journal STAND: Sports and Development \\
umipa Sumalaya & http://jurnal.unipasby.ac.id/index.php/stand/about/submissions \\
\hline
\end{tabular}

Tabel 3: Suharsimi Arikunto (2010: 326)

\begin{tabular}{|c|c|c|c|c|}
\hline No & Item & rpbis & Kriteria & Keterangan \\
\hline 1 & $\mathrm{P} 1$ & 0,61 & \multirow{15}{*}{$>0.3$} & Valid \\
\hline 2 & $\mathrm{P} 2$ & 0,54 & & Valid \\
\hline 3 & P3 & 0,39 & & Valid \\
\hline 4 & P4 & 0,52 & & Valid \\
\hline 5 & P5 & 0,68 & & Valid \\
\hline 6 & P6 & 0,50 & & Valid \\
\hline 7 & $\mathrm{P} 7$ & 0,53 & & Valid \\
\hline 8 & P8 & 0,58 & & Valid \\
\hline 9 & $\mathrm{P9}$ & 0,61 & & Valid \\
\hline 10 & $\mathrm{P} 10$ & 0,64 & & Valid \\
\hline 11 & P11 & 0,51 & & Valid \\
\hline 12 & $\mathrm{P} 12$ & 0,51 & & Valid \\
\hline 13 & $\mathrm{P} 13$ & 0,61 & & Valid \\
\hline 14 & P14 & 0,52 & & Valid \\
\hline 15 & $\mathrm{P} 15$ & 0,50 & & Valid \\
\hline
\end{tabular}

2. Uji Reliabilitas

Uji reliabilitas butir tes menggunakan perhitungan menggunakan rumus K-R 20 (Suharsimi Arikunto, 2010: 230). Instrumen kuesioner reliabel karena nilai koefisien KR 20 sebesar 0.78 atau lebih besar dari 0.60 .

Tabel 4: hasil nilai reliabilitas

\begin{tabular}{ccc}
\hline KR & & \\
20 & Kriteria & Keterangan \\
\hline 0.86 & $>0.60$ & Reliabel \\
\hline
\end{tabular}

\section{Deskripsi Data Penelitian}

Penelitian ini merupakan penelitian deskriptif, yaitu penelitian yang melukiskan keadaan objek yang sebenarnya. Data yang dimaksud dalam penelitian ini adalah data yang diperoleh dengan menggunakan metode survei dengan teknik kuesioner/angket. Sebelum memberikan kuesioner/angket penelitian ini peneliti memberi informasi terkait tujuan penelitian, dengan tujuan agar atlet dapat mengisi angket sesuai dengan keadaan sebenarnya. Penyebaran angket dilakukan mulai pada tanggal 17 dan 18 November tahun 2020 dengan responden berjumlah 15 orang. Hasil deskripsi analisis jawaban hasil penelitian dapat dilihat dalam tabel di bawah ini:

Tabel 5: Hasil Analisis Deskriptif

\begin{tabular}{cccc}
\hline Variebel & Indikator & Persentase & $\begin{array}{c}\text { Persentase } \\
\text { Variabel }\end{array}$ \\
\hline Perilaku & Perilaku & $64,17 \%$ & \\
Atlet & Peran & & $70.72 \%$ \\
pada & Hubungan & $74,67 \%$ & \\
Masa & Sosial & & \\
Covid- & Perilaku & $73,33 \%$ & \\
19 & Ekspresif & & \\
\hline
\end{tabular}

\section{Hasil Penelitian}

Dalam penelitian yang terkait dengan perilaku Atlet pada masa covid-19 didapatkan hasil persentase sebagai berikut: 1) Indikator perilaku hubungan sosial didapatkan hasil persentase $74,67 \%$. 2) Indikator perilaku ekspresif didapatkan hasil persentase 73,33\%. Indikator perilaku peran didapatkan hasil persentase $64,17 \%$.

\section{KESIMPULAN}

Dalam penelitian analisis perilaku atlet PAB Forki DIY dalam mendukung performance latihan selama pandemi covid19 dapat ditarik kesimpulan sebagai berikut:

1. Indikator hubungan sosial: a) $93.33 \%$ berkomunikasi dengan orang tua untuk mendukung program, b) $80.00 \%$ latihan karena motivasi dari orang tua, c) $73.33 \%$ latihan karena motivasi dari pelatih, d) 


\begin{tabular}{|c|c|c|}
\hline & Journal STAND: Sports and Development \\
umipa Sumalaya & http://jurnal.unipasby.ac.id/index.php/stand/about/submissions \\
\hline
\end{tabular}

$66,67 \%$ memiliki teman latihan, dan e ) $60.00 \%$ menambah jam latihan privat dengan pelatih.

2. Indikator perilaku ekspresif: a) $93.33 \%$ memiliki motivasi tinggi dalam berlatih selama masa pandemi, dan b) $53.33 \%$ jenuh latihan selama masa pandemi.

3. Indikator perilaku peran: a) $80.00 \%$ selalu latihan mandiri selama masa pandemic, b) $80.00 \%$ menjalankan program latihan dari pelatih, c) $80.00 \%$ antusias mencari referensi latihan selama pandemi, d) $80.00 \%$ mengatur gizi selama untuk mempertahankan performance latihan, e) $66.67 \%$ selalu menambah latihan sendiri diluar program dari pelatih, f) $60.00 \%$ mengatur tidur selama untuk mempertahankan performance latihan, g) $40.00 \%$ selalu mengikuti latihan yang bersifat online, h) $26.67 \%$ selalu menambah latihan sendiri diluar program dari pelatih

\section{REFERENSI}

Ali Maksum. (2008). Metode Penelitian Olahraga. Surabaya: Unessa Press.

Anas Sudijono. (2006). Pengantar Statistik Pendidikan. Jakarta: PT.Raja Grafindo Persada.

Hadari Nawawi. (2007). Manajemen Sumber Daya Manusia Untuk Bisnis Yang Kompetitif. Yogyakarta: Gajah Mada University Pres.

Hurlock, (2003). Psikologi Perkembangan. Erlangga, Jakarta
Saifuddin Azwar. (2012). Metode Penelitian. Yogyakarta: Pustaka Pelajar.

Sugiyono. (2011). Metode penelitian pendidikan: pendekatan kuantitatif, kualitatif, dan $R$ \& $D$. Bandung: Alfabeta.

(2013). Metode penelitian pendidikan: pendekatan kuantitatif, kualitatif, dan $R \& D$. Bandung: Alfabeta.

Suharsimi Arikunto. (2013). Prosedur Penelitian: Suatu Pendekatan Praktik. Jakarta: Rineka Cipta.

WHO. (2020). WHO Director-General's remarks at the media briefing on 2019-nCov on 11 February 2020. Cited Feb 13rd 2020. Available on: https://www.who.int/dg/speeches/d etail/who-director-generalsremarks-at-the-media-briefing-on2019-ncov-on-11-february-2020. (Feb 12th 2020)

Widha Srianto. (2014). Pengembangan Model Latihan Karate Kids Pada Anak Usia Sekolah Dasar Kelas Atas (10-12 Tahun). Thesis. Yogyakarta: Pasca Sarjana UNY.

Yuliana. (2020). Corona Virus Diseases (Covid-19): Sebuah Tinjauan Literatur. Wellness and healthy magazine, Vol 2 No 1. Lampung: Fakultas Kedokteran Universitas Lampung. 